\title{
Impact of Domestic Solid Waste Management on Wet Land Water Quality: Case of Abomey-Calavi Municipality in Benin Republic
}

\author{
Nikita Topanou ${ }^{1,2^{*}}$, Jacques K. Fatombi ${ }^{1}$, Jean Gouvidé Gbaguidi ${ }^{3}$, Taofiki Aminou ${ }^{1}$, \\ Josse Gérard ${ }^{2,4}$, Mariane Domeizel ${ }^{2}$ \\ ${ }^{1}$ Faculty of Science and Technology, Natitingou Water and Environmental Chemistry Laboratory, Natitingou, Benin \\ ${ }^{2}$ Laboratoire Chimie Provence, Université Aix-Marseille/CNRS, Equipe Chimie Environnement Continental-3 Place Victor Hugo, \\ Marseille Cedex, France \\ ${ }^{3}$ Hydrology and Water Resources Management (Laboratory of Hydrology Applied), National Water Institute, Calavi, Benin \\ ${ }^{4}$ Laboratory for Physical-Chemical Analysis of Aquatic Environments (LAPMIA) of the Faculty of Science and Technology \\ (FAST) of Abomey-Calavi University (UAC-Rep of Benin), Abomey-Calavi, Benin \\ Email: *ntopanou12@gmail.com
}

How to cite this paper: Topanou, N. Fatombi, J.K., Gbaguidi, J.G., Aminou, T., Gérard, J. and Domeizel, M. (2021) Impact of Domestic Solid Waste Management on Wet Land Water Quality: Case of Abomey-Calavi Municipality in Benin Republic. Natural Resources, 12, 10-17.

https://doi.org/10.4236/nr.2021.121002

Received: November 14, 2020

Accepted: January 24, 2021

Published: January 27, 2021

Copyright $\odot 2021$ by author(s) and Scientific Research Publishing Inc. This work is licensed under the Creative Commons Attribution International License (CC BY 4.0).

http://creativecommons.org/licenses/by/4.0/

\begin{abstract}
The waste management is a major environmental challenge in all the countries. In the Republic of Benin, in absence of controlled landfill, the wetlands are filling in by solid household waste to set up housing environments. This study aimed at identifying the various forms of wetlands water pollutions originated by this practice. Physico-chemical parameters of sampling water were determined by using Ionic chromatography and spectrometry of atomic absorption. The microorganisms indicating fecal peril were identified by the conventional techniques of microbiology. Water quality of a witness well was also used to assess the general water quality of the backfilled wetland. The results revealed the water samples collected from backefilled wetlands were mineralized (898.32 \pm $6.13 \mu \mathrm{s} / \mathrm{cm})$, rich in chlorinate $(237.80 \pm 4.23 \mathrm{mg} / \mathrm{L})$ and nitrates ions $(224.10 \pm$ $3.42 \mathrm{mg} / \mathrm{L})$. They are more colored $(399.23 \pm 3.01 \mathrm{Pt} / \mathrm{Co})$ and more turbid $(62.5$ $\pm 2.48 \mathrm{NTU}$ ) than those of the unfilled wetlands. The results of microbiological analysis shown the presence of the cysts of Giardia lamblia (590/100 L) and cysts of Entamoeba histolytica (13/100 L) in all water, except those of witness well. The frequency of water contamination by bacteria indicating general degradation is $86.4 \%$. The embankment of the wetlands by the solid household waste leads to the water pollution.
\end{abstract}

\section{Keywords}

Domestic Solid Waste, Wetlands, Pollution, Micro-Organism 


\section{Introduction}

The integrated management of water resources passes by its protection, its preservation and its treatment according to its diverse uses. The protection of water resources against the pollution is a global concern, on which depends the survival of the human kind [1]. Water resources quality and quantity stakes are closely associated with their cleaning up (treatment). The serious challenges about the quality and the quantity of water resources are closely linked to those of their purification [1] [2]. The lack of infrastructures of water purification, the inappropriate collection and treatment of the solid household waste contribute strongly to the degradation of the quality of ground and surface waters of the urban cities of countries with limited resources [3]. Being the most drinking fluid water is also a potential source of transmitting diseases especially in developing counties. According to World Health Organization (WHO) survey, 80\% of all diseases in developing countries are water born [4].

According to [5], the management of the solid household waste has an impact on the environmental protection and on the health of the populations. In Benin Republic, the landfills are few; the practice of the embankment of wetlands by waste is the most common way for their management. This practice disturbs the functions assured by various elements of the ecosystems generating chemical, metallic and biological pollutions of surface and the groundwater [5] [6]; [7] noticed that about $80 \%$ of the solid household waste produced by Abomey-Calavi (CAC) municipality, the second biggest city of Benin are used to backfill the wetlands which, once filled in and stabilized, become residential areas where hand-dug wells are drilled for domestic water use. Hand-dug wells as the name implies are built manually and are little more than irregular holes in the ground, intersecting the water table [6]. The present study aims to assess the physico-chemical and microbiological characterization of waters from hand dug wells installed within $10 \mathrm{~m}$ circumference from wetlands in Abomey-Calavi Municipality to identify the various pollutions due to the embankment of these lands by the solid household waste.

\section{Material and Methods}

\subsection{Study Area}

The study was realized over a period of six months (March-August, 2009) in Abomey-Calavi city, the second urban community of Benin due to its population estimated to be about 1,000,000 habitants (RGPH3, 2008). The city's geographical coordinates are $6^{\circ} 26^{\prime} 46,8^{\prime \prime}$ latitude North and $2^{\circ} 20^{\prime} 53^{\prime \prime}$ longitude East, it is surrounded by numerous water courses, such as the Ouémé river, the Nokoué lake and the Atlantic Ocean.

We have chosen three (3) points of water sampling which localization is summarized in Table 1. Sampling was done in the properly cleaned plastic jars. These plastic sampling jars were rinsed three times before the sampling of 
Table 1. Geographical coordinates of well and wet landss waters.

\begin{tabular}{cc}
\hline Characteristics & spatiales Coordinats \\
\hline Hand dug wells on Backfilled wetlands & $\mathrm{N}^{\circ} 27^{\circ} 08.40^{\prime \prime}$ \\
& $\mathrm{E}^{\circ} 22^{\circ} 21^{\prime} 44.90^{\prime \prime}$ \\
Wetlands & $\mathrm{N}^{\circ} 26^{\prime} 08.70^{\prime \prime}$ \\
& $\mathrm{E} 002^{\circ} 21^{\prime} 46.50^{\prime \prime}$ \\
Witness hand dug Wells & $\mathrm{N} 06^{\circ} 27^{\prime} 45.60^{\prime \prime}$ \\
& $\mathrm{E}^{\circ} 02^{\circ} 20^{\prime} 57.6^{\prime \prime}$ \\
\hline
\end{tabular}

water. For every point of sampling, five samples are collected per month generating a total of 90 samples for six months. Sampled water was immediately analyzed just after the sampling.

\subsection{Physico-Chemical Analysis of Sampled Water}

Water analyzed are from unfilled wetlands, hand dug well on backfilled wetlands by domestic solid waste and witness well located approximately at $2 \mathrm{~km}$ from studied wetlands. The water samples takings, the preservation and their manipulation were made according to the rules of the International Standard Organization $\mathrm{n}^{\circ} 5667 / 3$ (1994). The $\mathrm{pH}$, the conductivity, the dissolved oxygen and the turbidity were determined in situ. The $\mathrm{pH}$ was determined by a $\mathrm{pH}$-meter WTW LF 340 Merck, the conductivity and the turbidity were respectively determined by the conductimeter WT 320 Merck, and the turbidimeter HACH on 2100 the YEAR ORCHIDIS. We have used the oximeter HANNA to assess the dissolved oxygen. Total Organic Carbon (TOC) was measured by an analyzer of Solid Module Shimadzu SSM 5000. Anions likes, nitrates, chlorides and nitrites, were measured by DIONEX ICS-3000 ionic chromatograph [8]. Heavy metals such as Lead $(\mathrm{Pb})$, Cadmium $(\mathrm{Cd})$, Chrome $(\mathrm{Cr})$ and Nickel $(\mathrm{Ni})$ were measured by ICP AES JY on 2000 sequential Ultrace [9].

\subsection{Microbiological Analysis of Sampled Water}

Microbiological examinations are practiced to look for protozoon in particular the cysts of Giardia and Amoeba. A total enumeration of bacteria was realized according to the method of the Center of Expertise of Quebec [10].

The bacteria indicating a faecal contamination such as Escherichia coli ( $E$ coii), Enterococcus and opportunist pathogen (Staphylococcus aureus, Staphylococcus scuiri, Pseudomonas aeruginosa) were identified by conventional method as described by [11].

The results obtained were processed and analyzed using the software SPSS 19.1. The different proportions were compared by $\mathrm{x}^{2}$ test or Fischer at significance level of 0.05 .

\section{Results and Discussion}

\subsection{Physico-Chemical Properties}

Table 2 shows that backfilled wetlands sampled water was mineralized (898.32 \pm 
$6.13 \mu \mathrm{s} / \mathrm{cm})$ and rich in ions like chlorides, nitrates and nitrites. The turbidity of sampled water wetlands is $32.00 \pm 2.83 \mathrm{NTU}$ with $127.06 \pm 3.20 \mathrm{mg} / \mathrm{L}$ of total organic carbon. Heavy metals such as Lead and Cadmium had respectively a concentration of $4.62 \pm 1.19 \mu \mathrm{g} / \mathrm{L}$ and $0.38 \pm 0.13 \mu \mathrm{g} / \mathrm{L}$ in sampled water of backedfilled wetlands.

\subsection{Microbiological Characteristics of Water Samples}

The microscopic examinations revealed the presence of protozoons and particularly cysts of Giardia lamblia and Entomoeba hystolitica in all of the sampled water, except those of the witness well. A summary of the different microorganisms isolated during the study period are presented in Table 3. Microorganisms such as Enterococcus, Staphylococcus aureus Pseudomonas aeruginos and Staphylococcus scuiri were present in 78 water sampled and constituted $86.4 \%$. Escherichia coli are present more than 50 per $100 \mathrm{ml}$ for total coli forms and 2.5 per $100 \mathrm{ml}$ for E. coli.

Table 2. Physico-Chemical characteristics of well and wetlands waters.

\begin{tabular}{|c|c|c|c|}
\hline Parameters & $\begin{array}{l}\text { Waters of hand-dug well } \\
\text { on (backfilled wetlands) }\end{array}$ & $\begin{array}{l}\text { Waters of hand-dug well } \\
\text { on unfilled wetlands }\end{array}$ & $\begin{array}{l}\text { Witness hand } \\
\text {-dug well }\end{array}$ \\
\hline $\mathrm{pH}$ & $5.37 \pm 0.11$ & $6.78 \pm 0.42$ & $6.70 \pm 0.16$ \\
\hline Dissolve oxygen $(\mathrm{mg} / \mathrm{L})$ & $0.50 \pm 0.24$ & $2.65 \pm 0.21$ & $3.8 \pm 0.35$ \\
\hline Conductivity $(\mu \mathrm{s} / \mathrm{cm})$ & $898.32 \pm 6.13$ & $369.0 \pm 5.09$ & $132 \pm 5.8$ \\
\hline Colour (Pt/Co) & $399.23 \pm 3.01$ & $221.0 \pm 1.70$ & $9.51 \pm 0.55$ \\
\hline Turbidity (NTU) & $62.5 \pm 2.48$ & $32.0 \pm 2.83$ & $1.5 \pm 0.35$ \\
\hline $\mathrm{COT}(\mathrm{mg} / \mathrm{L})$ & $198.92 \pm 5.35$ & $127.06 \pm 3.20$ & $88.72 \pm 2.21$ \\
\hline Total hardness $\left({ }^{\circ} \mathrm{F}\right)$ & $5.90 \pm 0.10$ & $6.50 \pm 0.10$ & $2.35 \pm 0.10$ \\
\hline $\mathrm{Cl}^{-}(\mathrm{mg} / \mathrm{L})$ & $237.80 \pm 4.23$ & $128.98 \pm 5.20$ & $89.72 \pm 2.85$ \\
\hline $\mathrm{NO}_{3}^{-}(\mathrm{mg} / \mathrm{L})$ & $224.10 \pm 3.42$ & $103.50 \pm 5.02$ & $57.46 \pm 2.21$ \\
\hline $\mathrm{NO}_{2}^{-}(\mathrm{mg} / \mathrm{L})$ & $4.24 \pm 0.02$ & $0.49 \pm 0.01$ & $0.03 \pm 0.01$ \\
\hline $\mathrm{SO}_{4}^{2-}(\mathrm{mg} / \mathrm{L})$ & $0.20 \pm 0.10$ & $0.50 \pm 0.10$ & $0.10 \pm 0.10$ \\
\hline
\end{tabular}

Table 3. Enumeration of coliform and pathogen bacteria in different water samples.

\begin{tabular}{ccccc}
\hline Parameters $($ CFU/m) & $\begin{array}{c}\text { Waters from wetlands } \\
\text { filled by waste. }\end{array}$ & $\begin{array}{c}\text { Waters from } \\
\text { unfilled wetlands }\end{array}$ & $\begin{array}{c}\text { P value } \\
\text { Test } \boldsymbol{X}^{2}\end{array}$ & $\begin{array}{c}\text { Witness } \\
\text { hand-dug Well }\end{array}$ \\
\hline $\begin{array}{c}\text { Faecal Coliform } \\
\text { Coliforms }\end{array}$ & $368,200 \pm 45,000$ & $5020 \pm 1020$ & 0.0001 & $2854 \pm 300$ \\
thermo-tolerant & $40,100 \pm 10,200$ & $6700 \pm 120$ & 0.00002 & $1894 \pm 250$ \\
Escherichia coli & $440,000 \pm 21$ & $35,000 \pm 2400$ & 0.004 & $400 \pm 35$ \\
$\begin{array}{c}\text { Staphylococcus aureus } \\
\text { Staphylococcus sciuri }\end{array}$ & $420000 \pm 45$ & $4500 \pm 220$ & 0.0001 & $1500 \pm 350$ \\
Pseudomonas aeruginosa & $540,000 \pm 15,230$ & $24,200 \pm 4500$ & 0.0006 & $350 \pm 15$ \\
Enterococcus & $456,000 \pm 720$ & $12,000 \pm 1030$ & 0.0003 & 05 \\
\hline
\end{tabular}




\section{Discussion}

The present study was focused on the physico-chemical and microbiological characterization of water sample from the wetlands to identify the various pollutions due to the embankment of wetlands by solid household waste. The results of this study revealed that sampled water from backedfill wetlands is more turbid (62.5 NTU) than those of wetlands (32 NTU). The water we analyzed is rich in organic substances with concentrations more important for water from backedfilled wetlands. This would be explained probably by the degradation of the organic substance contained in waste used to backfill the site of our study. According to [12] the degradation of the fermentable fractions of waste requires an important consumption of oxygen. Yet in countries with limited resources, the fermentable fraction of the solid household waste is about 50\% [5] [7]. As a consequence, the concentrations of oxygen dissolved by the water samples from backfilled wetlands by waste are low than those of wetlands. Water is said to be polluted when its quality is degraded as a result of man's activities to an extent that it becomes less suitable for its intended use [13]. Our result corroborated this finding.

Fecal coliforms were frequent in the sampled water and were more important in sampled water from backfilled wetlands. [14] made a correlation $(\mathrm{r}=0.59 ; \mathrm{p}=$ 0.001) between the presence of Enterococcus, $E$. coli and the degree of water pollution. These results confirmed those of [15] who underlined that a high value of the turbidity would foster the [16] proliferation of certain bacteria $(440,000$ $\mathrm{CFU} / \mathrm{ml}$ of $E$ coli. and 456,000 of Enterococcus). The values of $E$. coli identified in water of backfilled wetlands and wetlands are confirmed by the concentrations in nitrates and nitrites. Indeed, the concentrations of nitrites are higher in water from backfilled wetlands than in those of wetlands. This has shown a nitrogenous pollution of water from backedfill wetlands by the domestic solid waste [16]. The presence of nitrates in water from the backfilled wetlands would be due to a diffuse accumulation at the bottom of water column followed by a vertical transfer [17]. As the wetlands are shallow, the ions and the microorganisms of water from the polluted bottom infiltrate easily into the ground and contaminate the groundwater. Nitrites concentration is also a good indicator of the water pollution by the anthropological activities. This is probably the result of the nitrification, by the bacteria, of the ammonium ion obtained from the decomposition by ammonification of animals and the biodegradation of the household and agricultural waste [18]. The high value of nitrites in water from backedfilled wetlands confirms the important microbial flora. The concentrations of backfilled wetlands water in chlorides are higher than those from wetlands. As the chlorides ions are an indicator agent of water pollution by the solid household waste [16] [19], we would deduct that embankment of the wetlands by waste would be a cause of chemical and bacteriological pollution. The degree of mineralization (conductivity and $\mathrm{pH}$ ) also gives an indication on the level of water pollution [2]. The samples of analyzed water are weakly acid, this high 
Table 4. Metallic elements concentrations in water samples.

\begin{tabular}{cccc}
\hline Waters Parameters & $\begin{array}{c}\text { Waters from } \\
\text { wetlands filled by waste. }\end{array}$ & $\begin{array}{c}\text { Waters from unfilled } \\
\text { wetlands without waste }\end{array}$ & hand-dug well \\
\hline $\mathrm{Cd}(\mu \mathrm{g} / \mathrm{L})$ & $0.38 \pm 0.13$ & $0.10 \pm 0.03$ & $0.07 \pm 0.01$ \\
$\mathrm{Cr}(\mu \mathrm{g} / \mathrm{L})$ & $2.23 \pm 0.88$ & $0.38 \pm 0.11$ & $1.21 \pm 0.67$ \\
$\mathrm{~Pb}(\mu \mathrm{g} / \mathrm{L})$ & $4.62 \pm 1.19$ & $2.21 \pm 0.98$ & $3.21 \pm 1.22$ \\
$\mathrm{Ni}(\mu \mathrm{g} / \mathrm{L})$ & $2.06 \pm 0.71$ & $0.99 \pm 0.23$ & $0.28 \pm 0.07$ \\
\hline
\end{tabular}

acidity on the water from backfilled wetlands $(\mathrm{pH}=5.37 \pm 0.11)$ create an environment convenient to the proliferation of the pathogenic microorganisms, the source of pollution. An encouraging note in this study is the low concentration of metallic elements in the sampled water, particular heavy metals such as the Lead, the Cadnium and the Chromium (Table 4). Indeed, the sector of recycling of the metallic objects of waste is very developed in Abomey-Calavi city and would justify the low concentrations of heavy metals in backedfilled wetlands water.

Moreover hand pumps must be installed at least twenty meters away from the backfill land in order to minimize the seepage impact on the pumped water used for domestic used.

\section{Conclusions}

In summary, this study shows that the backfilled wetland water used for domestic purpose use is highly polluted and not suitable for human consumption. Therefore, alternate sources of drinking water must be explored especially the pumping of good quality drinking water.

This contamination finds its origins in the lack of the infrastructures of wastewater system and management of domestic solid waste. To sort different components of the waste, to store those on the landfills would be progress for the improvement of their management. Finally the efforts of raising awareness of the various actors on the protection of the ecosystems to discourage the practice of embankment have to be continued.

\section{Conflicts of Interest}

The authors declare no conflicts of interest regarding the publication of this paper.

\section{References}

[1] Guo, J., Xu, H., Zhang, G., Yuan, K. and Ling, H. (2020) The Enhanced Management of Water Resources Improves Ecosystem Services in a Typical Arid Basin. Sustainability, 12, 8802. https://doi.org/10.3390/su12218802

[2] Di Baldassarre, G., Sivapalan, M., Rusca, M., Cudennec, C., Garcia, M., Kreibich, H., et al. (2019) Sociohydrology: Scientific Challenges in Addressing the Sustainable Development Goals. Water Resources Research, 55, 6327-6355. 
https://doi.org/10.1029/2018WR023901

[3] UNO (2007) Water, a Shared Responsibility. The 2nd United Nations World Water Development Report, UNESCO, $550 \mathrm{p}$.

[4] Abedin, M.A., Collins, A.E. and Habiba, U. (2019) Climate Change, Water Scarcity, and Health Adaptation in Southwestern Coastal Bangladesh. International Journal of Disaster Risk Science, 10, 28-42. https://doi.org/10.1007/s13753-018-0211-8

[5] Parrot, L., Sotamenou, J. and Kamgnia Dia, B. (2009) Municipal Solid Waste Management in Africa: Strategies and Livelihoods in Yaoundé, Cameroon. Waste Management, 29, 986-995. https://doi.org/10.1016/j.wasman.2008.05.005

[6] Ravindra, K., Mor, S. and Pinnaka, V.L. (2019) Water Uses, Treatment, and Sanitation Practices in Rural Areas of Chandigarh and Its Relation with Waterborne Diseases. Environmental Science and Pollution Research, 26, 19512-19522. https://doi.org/10.1007/s11356-019-04964-y

[7] Topanou, N., Domeizel, M., Fatombi, J., Josse, R.G. and Aminou, T. (2011) Characterization of Household Solid Waste in the Town of Abomey-Calavi in Benin. Journal of Environmental Protection, 2, 669-676.

https://doi.org/10.4236/jep.2011.26080

[8] Rodier, J. (2005) L'analyse de l'eau. 8th Edition, DUNOD, Paris, 1381 p.

[9] N'Guessan, Y.M. (2008) Dynamic of Trace Elements in the Agricol Slope Bassin Surface Water of Gascogne. Doctorat Thesis of Toulouse University, Toulouse, 253 p.

[10] Ellouze, M., Saddoud, A., Dhouib, A. and Sayadi, S. (2009) Assessment of the Impact of Excessive Chemical Additions to Municipal Wastewaters and Comparison of Three Technologies in the Removal Performance of Pathogens and Toxicity. Microbiological Research, 164, 138-148.

https://doi.org/10.1016/j.micres.2006.11.007

[11] Ahoyo, T.A., Fatombi, K.J., Boco, M., Aminou, T. and Dramane, K.L. (2011) Impact de la qualité de l'eau et de l'assainissement sur la santé des enfants en milieu périurbain au Bénin: Cas des zones sanitaires Savalou-Banté et Dassa-Glazoué. Médécine Tropicale, $71,1-5$.

[12] Wang, R., Korboulewsky, N., Prudent, P., Domeizel, M., Rolando, C. and Bonin, G. (2010) Feasibility of Using an Organic Substrate in a Wetland System Treating Sewage Sludge: Impact of Plant Species. Bioresource Technology, 101, 51-57. https://doi.org/10.1016/j.biortech.2009.07.080

[13] Deng, S., Yan, X., Zhu, Q. and Liao, C. (2019) The Utilization of Reclaimed Water: Possible Risks Arising from Waterborne Contaminants. Environmental Pollution, 254, Article ID: 113020. https://doi.org/10.1016/j.envpol.2019.113020

[14] Rothrock, M.J. and Locatelli, A. (2019) Importance of Farm Environment to Shape Poultry-Related Microbiomes throughout the Farm-to-Fork Continuum of Pasture-Raised Broiler Flocks. Frontiers in Sustainable Food Systems, 3, 48. https://doi.org/10.3389/fsufs.2019.00048

[15] Wang, B., Gao, R., Wu, Z. and Yu, Z. (2020) Functional Analysis of Sugars in Modulating Bacterial Communities and Metabolomics Profiles of Medicago sativa Silage. Frontiers in Microbiology, 11, 641. https://doi.org/10.3389/fmicb.2020.00641

[16] Ismail, Z. (2011) Monitoring Trends of Nitrate, Chloride and Phosphate Levels in an Urban River. International Journal of Water Resources and Environmental Engineering, 3, 132-138.

[17] Gbaguidi, J.G., Topanou, N., Fatombi, J., Akpo, E., Mama, D. and Aminou, T. 
(2019) Contributions to the Protection of a Lentic System in the Tropical Region against Chemical Pollutions: A Case Study of "Toho Lake" in Southeastern Benin, West Africa. Journal of Bioscience and Applied Research, 6, 8-19.

https://doi.org/10.21608/jbaar.2020.115763

[18] Topanou, N., Gbaguidi, J.G., Akpo, E., Josse, R.G., Mama, D. and Aminou, T. (2020) Assessment of Some Heavy Metals in Fresh Fish (Oreochromis aureus): Case of Toho Lake in South Eastern Benin, West Africa. Journal of Geoscience and Environment Protection, 8, 159-172. https://doi.org/10.4236/gep.2020.83012

[19] Farid, S., Baloch, M.K. and Ahmad, S.A. (2012).Water Pollution: Major Issue in Urban Areas. International Journal of Water Resources and Environmental Engineering, 4, $55-65$. 